\title{
Clarification of used lubricating oils by application of chemically-modified clays
}

\section{(Clarificação de óleo lubrificante usado por aplicação de argilas quimicamente modificadas)}

\author{
M. S. L. Rosa ${ }^{1 *}$, T. Knoerzer ${ }^{2}$, F. C. Figueiredo ${ }^{I}$, J. R. dos Santos Júnior ${ }^{l}$ \\ ${ }^{1}$ Federal University of Piauí, Center of Natural Sciences, 64049-550, Teresina, PI, Brazil \\ ${ }^{2}$ US Air Force Academy, Department of Chemistry, CO80840, USA
}

\begin{abstract}
Clay is a material that exhibits excellent adsorbent properties which can be applied for the clarification of used motor oils. We describe a comparative analysis between natural and chemically-modified clays as an environmentally sound method of clarification. Previously, a sample of clay was chemically treated with $\mathrm{KOH}$ and $\mathrm{H}_{2} \mathrm{SO}_{4}$ with a concentration of $2.0 \mathrm{M}$ at $150{ }^{\circ} \mathrm{C}$. Both the natural and chemically-treated samples were characterized using the techniques of XRD, FTIR, SSA, and thermal analysis to observe the structural change after the chemical treatment. These characterizations indicated that there was an increase in surface area and microporous space creation in the acid-treated sample as a result of the clay exfoliation. The acid-treated sample exhibited the potential of clarification of waste oil and high performance relative to the natural sample and the base-treated sample.
\end{abstract}

Keywords: clay, clarifying, waste lubricant oil.

\section{Resumo}

Argila é um material que exibe excelentes propriedades adsorventes que pode ser aplicada para a clarificação de óleos de motor usado. Descreve-se uma análise comparativa entre argilas natural e quimicamente modificadas como um método de clarificação ambientalmente correto. Previamente a argila foi tratada quimicamente com $\mathrm{KOH}$ e $\mathrm{H}_{2} \mathrm{SO}_{4}$ com concentração $2,0 \mathrm{M}$ a $150{ }^{\circ} \mathrm{C}$. Amostras natural e quimicamente tratadas foram caracterizadas usando as técnicas de DRX, FTIR, SSA e análise térmica para observar a mudança estrutural após o tratamento químico. Estas caracterizações indicaram que houve aumento na área superficial e criação de espaço microporoso na amostra tratada com ácido, como resultado da esfoliação da argila. A amostra tratada com ácido exibiu potencial de clarificação do óleo usado e alto desempenho em relação à amostra natural e amostra tratada com base. Palavras-chave: argila, clarificante, óleo lubrificante usado.

\section{INTRODUCTION}

Motor lubricant oil is an important product needed in the operation of the internal combustion engine but is known to suffer degradation by temperature and other chemical reactions. Most notably, oxidation and the formation of reaction by-products such as organic acids, ketones, and polynuclear aromatic hydrocarbons (PAHs) result in a deep black-colored product that is highly viscous and comprised of potentially carcinogenic compounds [1-3]. Ultimately, the 'burned oil' product that is generated poses a serious environmental concern and is thus worthy of remediation. One of the primary means of remediation is the incineration of the spent oil, but this method has the clear disadvantage of releasing high concentrations of dioxins in air and landfills, thus contaminating the soils and also limiting the potential for material recovery [4-7]. Indeed, recovery is the most

*mirnasales01@hotmail.com

Dhttps://orcid.org/0000-0003-3509-9824 desirable means of remediation, both environmentally and economically [7]. However, the most commonly used industrial treatment process consumes considerable time and energy due to the various reagents employed and the extensive steps needed to achieve clarification of the used or contaminated oil [8-11].

To reduce the amount of time, energy, and resources needed, several studies have simplified the process to obtain a lubricant that complies with the laws in force to only two steps: a) extraction with polar solvents with up to four carbon atoms such as methanol, ethanol, isopropanol, or butanol; and $b$ ) clarification using adsorbent materials such as peanut shell, nutshell, eggshell, natural clay, or acid clay [1-24]. Among the adsorbent materials, clays appear to be the most attractive option because these materials are easily found in nature, have a low cost, and are non-toxic. Furthermore, the clays may contain other weathered minerals such as quartz, kaolinite, and palygorskite, which have also been widely applied in the clarification processes of vegetable, animal, and mineral oils due to the presence of a negative charge moiety within the structure of silicate minerals [13-20]. This 
negative charge can be counteracted by the adsorption of positively charged cations such as dyes [21]. In addition, clays have a large surface area, which contributes to their high adsorption capacity, and consequently, for the oil clarification [21-22].

In the chemical industry, natural clays are modified with acid to enhance the clarification process. In acid-activated clay, acid attacks the edges of the mineral coverslips, leading to exfoliation and generating pores on the surfaces of the coverslips, ensuring the increase of specific surface and pore volume, which in turn ensures greater adsorption. Besides, acid activation dissolves organic and inorganic impurities and replaces diatomic and triatomic cations by $\mathrm{H}^{+}$ions (Fig. 1a). Perhaps this can be attributed to the clay functioning as a Bronsted-Lowry acidic active site of which can adsorb organic impurities such as anionic dyes by electrostatic attraction (Fig. 1b) or even covalent bonding, such as cationic dyes (Fig. 1c) [19, 20]. The acid-modified approach appears to produce a distinct opportunity to apply this chemical approach in conjunction with a clay matrix in order to provide an ideal combined approach for successful oil remediation. Therefore, we report the use of modified clays for the clarification of lubricating oils by application of $\mathrm{KOH}$ and $\mathrm{H}_{2} \mathrm{SO}_{4}$ chemical modification. Our findings are further illustrated by the observed changes in the structure and specific surface area determinations of both untreated and treated clays.

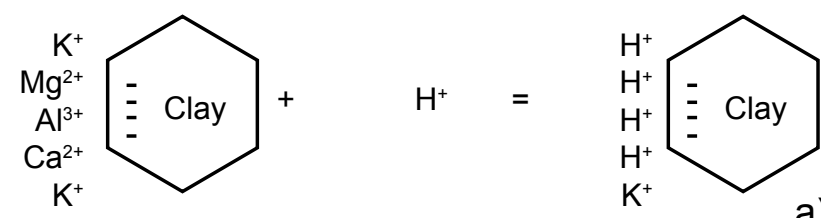

a)

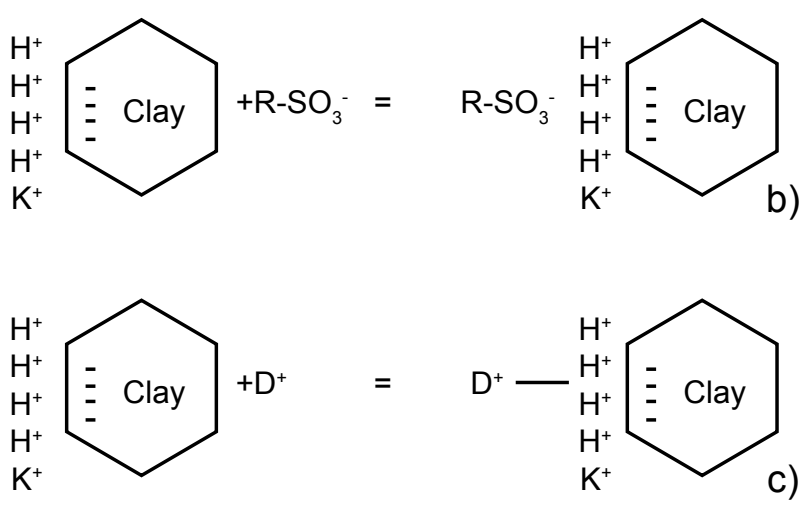

Figure 1: Illustrations of: a) cation exchange between acidic $\mathrm{H}^{+}$ ions and clay cations; b) adsorption mechanisms by electrostatic attraction between clay and anionic dye $\left[\mathrm{R}-\left(\mathrm{SO}_{3}\right)^{-}\right]$; and $\mathrm{c}$ ) adsorption mechanism by covalent bonding between clay and cationic dye $\left(\mathrm{D}^{+}\right)$.

[Figura 1: Ilustração de: a) troca catiônica entre íons $\mathrm{H}^{+}$do ácido $e$ os cátions da argila; b) mecanismo de adsorção por atração eletrostática entre a argila e corante aniônico [R-( $\left.\left.\mathrm{SO}_{3}\right)^{-}\right]$; e c) mecanismo de adsorção por ligação covalente entre a argila $e$ corante catiônico $\left(D^{+}\right)$.]

\section{MATERIALS AND METHODS}

Clay preparation: a clay was acquired from a mine in the city of Guadalupe, State of Piauí, Brazil. Initially, the natural sample was submitted to a manual quartering process in order to obtain a more homogeneous final sample. The clay was hammer milled and macerated with a porcelain mortar and pestle. Subsequently, the sample was sifted in a 120 mesh sieve and dried at $80 \pm 10{ }^{\circ} \mathrm{C}$ for $12 \mathrm{~h}$ to eliminate the excess water from the sample. Clay chemical modification: from the previously dried and disaggregated natural sample, two $4 \mathrm{~g}$ portions of clay were weighed and subjected to chemical treatment with solutions $2 \mathrm{M} \mathrm{KOH}$ (reagent grade, Dinâmica) and $2 \mathrm{M} \mathrm{H}_{2} \mathrm{SO}_{4}$ (reagent grade, Dinâmica), and then treated at $150^{\circ} \mathrm{C}$ for $6 \mathrm{~h}$ in an oven with a heating rate of $10^{\circ} \mathrm{C} / \mathrm{min}$. The resulting samples were labeled as CNAT for natural clay, and $\mathrm{CTKOH}$ and $\mathrm{CTH}_{2} \mathrm{SO}_{4}$ for the clays treated with potassium hydroxide and sulfuric acid, respectively.

$X$-ray diffraction $(X R D)$ : the clay samples before and after chemical modification were characterized by XRD using a Malvern Panalytical Empyrean diffractometer, in the $2 \theta$ range between $1.4^{\circ}$ and $70^{\circ}$ with $\mathrm{CoK} \alpha$ radiation (wavelength of $1.79290 \AA$ ), and a scan speed of $5 \%$ min. Fourier-transform infrared spectroscopy (FTIR): analyses were performed using $\mathrm{KBr}$-containing pellet sample using Perkin Elmer 100FT-IR spectrometer (in the region from 4000 up to $400 \mathrm{~cm}^{-1}$ ) with 16 scans and resolution of 4 $\mathrm{cm}^{-1}$. Specific surface area (BET): for obtaining nitrogen adsorption-desorption isotherms, the samples of CNAT, $\mathrm{CTKOH}$, and $\mathrm{CTH}_{2} \mathrm{SO}_{4}$ were degassed at $100{ }^{\circ} \mathrm{C}$ for 16 h. Surface area measurements, from physical adsorption of nitrogen, were obtained at $77 \mathrm{~K}$ using a Quantachrome NOVA 10.01 analyzer to estimate the possible changes on the clay surface. Thermal analysis: thermogravimetric (TG) analysis was performed in a TA Instr. V20.9 SDT Q600, using an inert atmosphere of nitrogen with a gas flow of $100.0 \mathrm{~mL} / \mathrm{min}$ and a heating rate of $20^{\circ} \mathrm{C} / \mathrm{min}$. Samples were prepared precisely with a mass of $18.5080 \mathrm{mg}$ using alumina crucibles and the temperature range for heat cycling was from 20 to $600{ }^{\circ} \mathrm{C}$.

Extraction and yield of the isoamyl pre-treated oil: the lubricating oil was semi-synthetic with a viscosity classification of SAE $15 \mathrm{~W}-40$ and was purchased commercially. The used lubricating oils were supplied by Garagem do Monobloco (Teresina, Brazil), by removal from select petrol motor vehicles with a total odometer value of $15000 \mathrm{~km}$. Isoamyl alcohol (PA, Dinâmica) was used in the crude oil extraction process with a 3:1 proportion of isoamyl alcohol to lubricating oil. The mixture was stirred for $30 \mathrm{~min}$, and a precipitate of additives, impurities, and carbonaceous particles was formed. The precipitate was separated from the supernatant by filtration. Then, the alcohol was removed from the oil by rotary evaporation. The yield of resulting pretreated oil was determined in comparison with the original amount of crude oil. Application of clay samples to clarify isoamyl pre-treated oil: the clarification process of the used lubricating oil was according to the ASTM D1500 standard 
[25]. The lubricant clarification process was performed after pre-treatment with isoamyl alcohol. The resulting pretreated oil sample was then submitted to the clarification process initially by eluting with a ratio of lubricant:hexane 1:1 (w/w). Both natural and treated clays were clarified using the same process. Fractions from filtration were collected and transferred to the vacuum distillation flask to recover the solvent and obtain the lubricant clarified at $50{ }^{\circ} \mathrm{C}$. The resultant clarified oil was stored in an amber container for subsequent physicochemical characterization.

Physicochemical characterization of oil samples: the lubricating oils samples were characterized by the ASTM D1500-12 color [25], kinematic viscosity at 40 and 100 ${ }^{\circ} \mathrm{C}$ (ASTM D445-18) [26], total number of acidity (ASTM D974-04) [27] and ash content (ASTM D 482-13) [28]. Colorimetric analysis: the color measurement of the new lubricating oil (OLN), used lubricating oil (OLU), lubricating oil clarified with natural clay (OLCCNAT), lubricating oil clarified with clay and $\mathrm{KOH}(\mathrm{OLCCTKOH})$, and lubricating oil clarified with clay and $\mathrm{H}_{2} \mathrm{SO}_{4}\left(\mathrm{OLCCTH}_{2} \mathrm{SO}_{4}\right)$ was performed using a Seta-Lovibond Color Voltage 24v 15260$4 \mathrm{U}$ instrument. Comparisons were made between the color of the analyzed samples and the Lovibond colors scale, which considers the measures of color to red and yellow. This technique comprises the combination of the color of the light transmitted through a specific depth of oil with the color of the light transmitted from the same source of the set of filters as the reference color [25]. Kinematic viscosity: was determined by the product of the time of the constant flow of Cannon-Fenske: 150 capillary viscometer at 100 ${ }^{\circ} \mathrm{C}$; and 300 viscometer at $40{ }^{\circ} \mathrm{C}$. The measurements were performed using a Quimis Q383SR26 automatic viscometer [26]. Total number of acidity: the acidity of the samples of lubricants was measured by the amount of potassium hydroxide required for neutralization ( $\mathrm{mg} \mathrm{KOH} / \mathrm{g}$ lubricant) and resulting in the total number of acidity [27]. Ash content: the lubricating oil samples were transferred to a crucible and burned until they became ashes and carbon. Carbonaceous residues of the samples were reduced to ashes by heating in an oven at approximately $775^{\circ} \mathrm{C}$, cooled, and weighed [28]. UV-vis analysis: the capacity of natural sample and chemically-activated clays to discolor the used lubricating oil was determined using a digital Thermo Fisher Sci., Genesys 10S, UV-vis spectrophotometer operating from 100 to $1000 \mathrm{~nm}$. Hexane was used to dilute the samples in the proportion of 1:10, and all the measurements were performed in triplicate [12].

\section{RESULTS AND DISCUSSION}

Initially, the results of X-ray diffraction (XRD) were evaluated to determine the matrix consistencies of the clay material employed in this study. The XRD pattern of the natural sample (Fig. 2a) showed reflections that were typically indexed to palygorskite $\left[\mathrm{Mg}_{5} \mathrm{Si}_{8} \mathrm{O}_{20}(\mathrm{OH})_{2}\left(\mathrm{OH}_{2}\right)_{4} \cdot 4 \mathrm{H}_{2} \mathrm{O}\right]$, kaolinite $\left[\mathrm{Al}_{2} \mathrm{Si}_{2} \mathrm{O}_{5}(\mathrm{OH})_{4}\right]$, and quartz $\left(\mathrm{SiO}_{2}\right)$, all of which were consistent with the files JCPDF 00-021-0958, 00-029-
1488, and ICSD 01-079-1910, respectively. The reflection of higher intensity of palygorskite at $10.14^{\circ}(\mathrm{d}=10.11$ $\AA$ ) corresponded to the plane (110), and at $22.88^{\circ} \mathrm{d}=4.50$ $\AA$ [12-17]. The presence of kaolinite was implicated by reflections at $14.35^{\circ}(\mathrm{d}=7.16 \AA), 29.25^{\circ}(\mathrm{d}=3.54 \AA)$, and $73.06^{\circ}(\mathrm{d}=1.50 \AA)$. The presence of quartz corresponded to reflections at $24.41^{\circ}(\mathrm{d}=4.23 \AA), 31.03^{\circ}(\mathrm{d}=3.34 \AA), 40.46^{\circ}$ $(\mathrm{d}=2.58 \AA), 42.88^{\circ}\left(\mathrm{d}=2.44^{\circ} \AA\right)$, and $58.92^{\circ}(\mathrm{d}=1.81 \AA)$. For the chemically-activated clay with $\mathrm{H}_{2} \mathrm{SO}_{4}$ sample (Fig. 2b), there was a gradual reduction in intensity and widening of the peaks in the palygorskite and kaolinite phases because of clay exfoliation [29]. Furthermore, the presence of quartz was maintained in the sample $\mathrm{CTH}_{2} \mathrm{SO}_{4}$, which suggested that the chemical treatment had little influence in this phase. With regard to the CTKOH sample (Fig. 2c), there was a slight reduction and widening of peaks of all crystalline phases, suggesting that chemical treatment had little influence on palygorskite, kaolinite, and quartz phases.
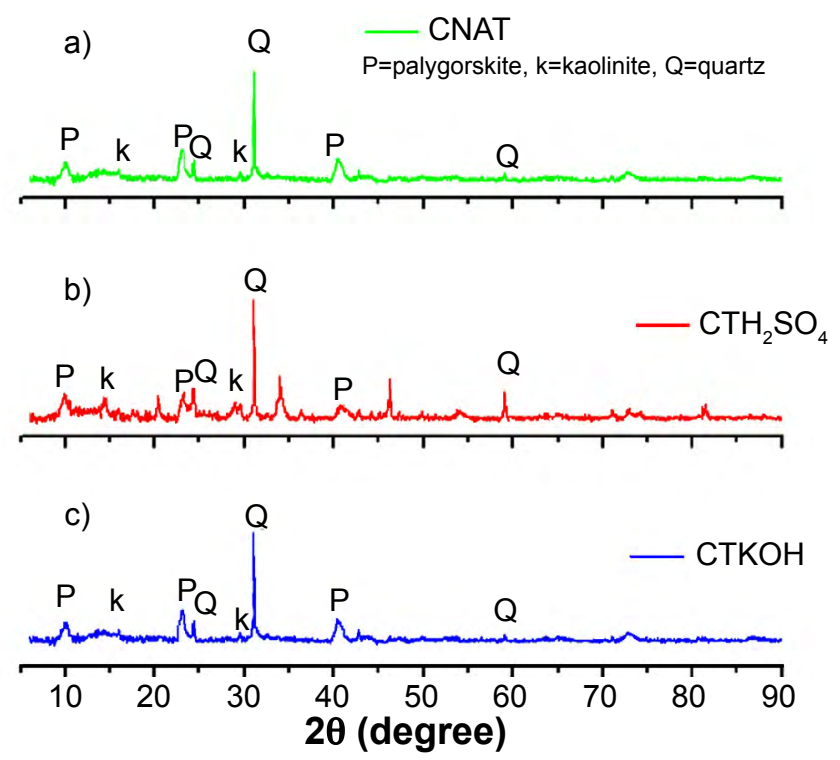

Figure 2: XRD patterns of the samples: a) CNAT; b) $\mathrm{CTH}_{2} \mathrm{SO}_{4}$; and c ) $\mathrm{CTKOH}$.

[Figura 2: Padrões de DRX das amostras: a) CNAT; b) $\mathrm{CTH}_{2} \mathrm{SO}_{4}$; e c) CTKOH.]

Fig. 3 shows the results of infrared spectroscopy of the samples CNAT (Fig. 3a), $\mathrm{CTH}_{2} \mathrm{SO}_{4}$ (Fig. 3b), and $\mathrm{CTKOH}$ (Fig. 3c). The bands at 3705 and $3618 \mathrm{~cm}^{-1}$ corresponded to the hydroxyl mixture of clay minerals (palygorskite and kaolinite) linked to metal (Me), where Me corresponds to the ions $\mathrm{Al}^{3+}, \mathrm{Mg}^{2+}$ or $\mathrm{Fe}^{3+}$ [30-36]. The bands in the range from 3406 to $3516 \mathrm{~cm}^{-1}$ were attributed to the elongation vibrational mode of water absorbed by clay [12]. The band at $1643 \mathrm{~cm}^{-1}$ represented the deformation of water molecules [19] and at $913 \mathrm{~cm}^{-1}$ of the octahedral leaf (Al-OH) [17]. The absorption at $1029 \mathrm{~cm}^{-1}$ referred to the stretching of $\mathrm{Si}-\mathrm{O}$ groups from the tetrahedral sheet for kaolinite and palygorskite [34-38]. The band at $796 \mathrm{~cm}^{-1}$ was attributed to the quartz impurity crystalline phase [34]. The bands at 682 and $537 \mathrm{~cm}^{-1}$ were attributed to angular deformation of 
Si-O-Me [33], and around $467 \mathrm{~cm}^{-1}$ corresponded to Si-O-Si [37-40]. After the chemical modification, the bands from 3706 to $3406 \mathrm{~cm}^{-1}$ disappeared in both $\mathrm{CTKOH}$ and $\mathrm{CTH}_{2} \mathrm{SO}_{4}$ spectra. The disappearance of these bands confirmed the leaching of clay due to chemical treatment [17-30]. The bands presented in the region of shorter wavelength, for example at 1029, 913, 796, 682, 537 and $467 \mathrm{~cm}^{-1}$, corresponded to vibrations related to the silica. Silica retention in samples of CTKOH and $\mathrm{CTH}_{2} \mathrm{SO}_{4}$ suggested that the chemical treatment had
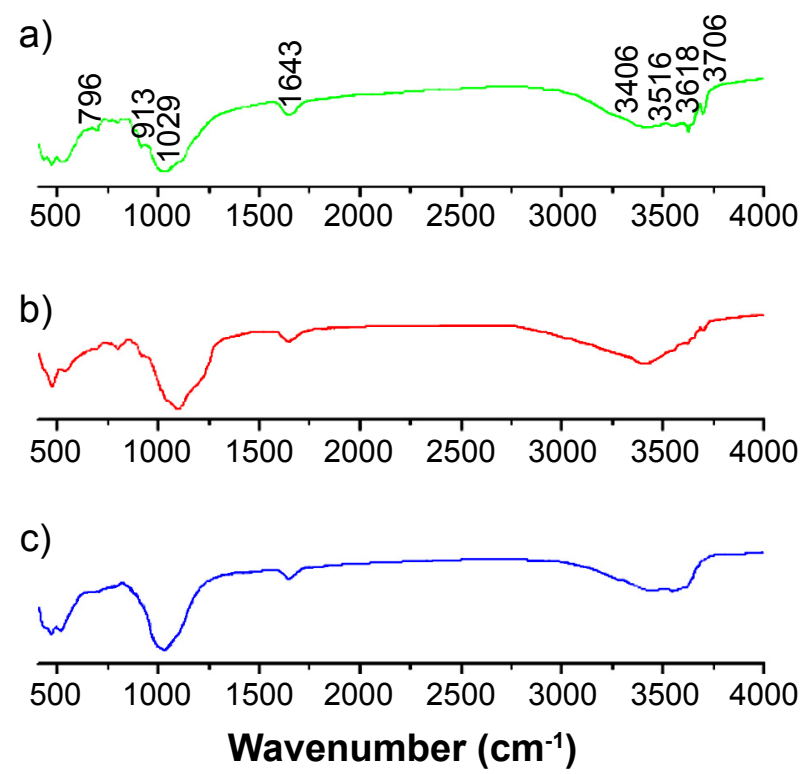

Figure 3: FTIR spectra of the samples: a) CNAT; b) $\mathrm{CTH}_{2} \mathrm{SO}_{4}$; and c) $\mathrm{CTKOH}$.

[Figura 3: Espectros de FTIR das amostras: a) CNAT; b) $\mathrm{CTH}_{2} \mathrm{SO}_{4}$; e c) $\mathrm{CTKOH}$.

Table I - Allocation of the vibration bands on the infrared spectrum of clay.

[Tabela I - Atribuição das bandas de vibração no espectro infravermelho da argila.]

\begin{tabular}{ccc}
\hline $\begin{array}{c}\text { Wavenumber } \\
\left(\mathrm{cm}^{-1}\right)\end{array}$ & Attribution & Ref. \\
\hline 3706 & Stretching OH-Me & {$[30-36]$} \\
3618 & Stretching OH-Me & {$[30-36]$} \\
3516 & Stretching $\mathrm{H}_{2} \mathrm{O}$ & {$[12]$} \\
3406 & Stretching $\mathrm{H}_{2} \mathrm{O}$ & {$[12]$} \\
1643 & Deformation $\mathrm{H}_{2} \mathrm{O}$ & {$[17]$} \\
1029 & Stretching Si-O & {$[34-38]$} \\
913 & Deformation Al-OH & {$[17]$} \\
796 & Stretching Si-O-Si & {$[34]$} \\
682 & Angular deformation & {$[33]$} \\
& Si-O-Me & {$[33]$} \\
537 & Angular deformation & Si-O-Me \\
467 & Stretching Si-O-Si & {$[34,37-40]$} \\
\hline
\end{tabular}

little influence on the quartz phase, corroborating the XRD results. The main observed bands presented in the IR spectral data set are briefly specified in Table I.

Fig. 4 shows adsorption-desorption isotherms of nitrogen for $\mathrm{CTKOH}, \mathrm{CTH}_{2} \mathrm{SO}_{4}$, and CNAT. Each isotherm seemed to indicate type IV behavior with the presence of both meso and micropores (IUPAC classification) [41]. In Table II, the sample chemically-treated with acid showed a higher specific surface area $\left(152.0 \mathrm{~m}^{2} / \mathrm{g}\right)$ in comparison with the samples CTKOH $\left(113.8 \mathrm{~m}^{2} / \mathrm{g}\right)$ and CNAT $\left(124.6 \mathrm{~m}^{2} / \mathrm{g}\right)$. The pore volume was $0.047 \mathrm{~cm}^{3} \cdot \mathrm{g}^{-1}$ for CTKOH, $0.051 \mathrm{~cm}^{3} \cdot \mathrm{g}^{-1}$ for CNAT, and $0.063 \mathrm{~cm}^{3} \cdot \mathrm{g}^{-1}$ for $\mathrm{CTH}_{2} \mathrm{SO}_{4}$. The increase in the specific surface area and pore volume in $\mathrm{CTH}_{2} \mathrm{SO}_{4}$ can be attributed to the leaching of cations $\mathrm{Al}^{3+}$ and $\mathrm{Mg}^{2+}$ of octahedral leaf, dehydroxylation of silanol and aluminol groups from tetrahedral and octahedral leaves of clay, and consequent progressive destruction of the chemical structure and generation of meso and microporous space with Bronsted-Lowry acidic sites after the acid treatment [30].

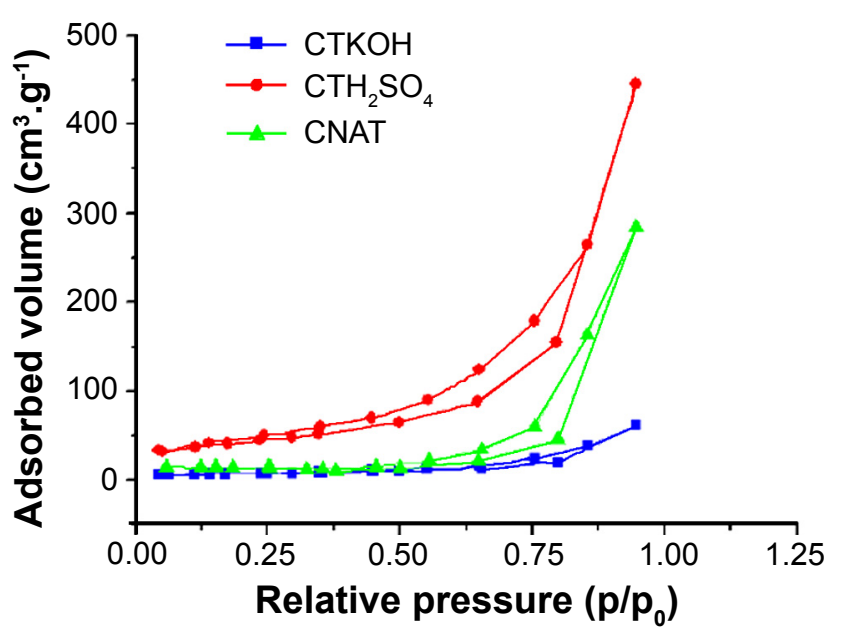

Figure 4: Nitrogen adsorption-desorption isotherms of the clay samples.

[Figura 4: Isotermas de adsorção-dessorção de nitrogênio das amostras de argila.]

TG/DTG analysis provided information about the changes following chemical treatment, further delineating the range of mass losses. Fig. 5 shows the thermal behavior of clay under a nitrogen atmosphere (TG/DTG curves for CNAT, CTKOH, and $\mathrm{CTH}_{2} \mathrm{SO}_{4}$ ). The samples had thermal events that were related to the mass loss of water from clay [17-30]. CNAT displayed three distinct events (Fig. 5). The first event occurred in the range between 20 and $126{ }^{\circ} \mathrm{C}$ and was associated with the release of physically adsorbed water [12], showing a loss of mass (PM1) of $7.25 \%$. The second event occurred in the range between 126 and $287^{\circ} \mathrm{C}$, with a loss of mass of approximately 1.5\% (PM2), which corresponded to the loss of mass of zeolitic water present in the channels [15-17]. Finally, the third event occurred in the range between 287 and $600{ }^{\circ} \mathrm{C}$ with a loss of mass of $7.05 \%$ (PM3) and was related to water loss and loss of the hydroxyls of the silanol (Si-OH) and aluminol groups 
Table II - Results of specific surface area and pore volume of CNAT, $\mathrm{CTH}_{2} \mathrm{SO}_{4}$, and CTKOH.

[Tabela II - Resultados de área superficial específica e volume de poros de CNAT, $\mathrm{CTH}_{2} \mathrm{SO}_{4}$ e CTKOH.]

\begin{tabular}{ccc}
\hline Sample & $\begin{array}{c}\text { Surface area } \\
\left(\mathrm{m}^{2} \cdot \mathrm{g}^{-1}\right)\end{array}$ & $\begin{array}{c}\text { Pore volume } \\
\left(\mathrm{cm}^{3} \cdot \mathrm{g}^{-1}\right)\end{array}$ \\
\hline $\mathrm{CNAT}$ & 124.6 & 0.051 \\
$\mathrm{CTKOH}$ & 113.8 & 0.047 \\
$\mathrm{CTH}_{2} \mathrm{SO}_{4}$ & 152.0 & 0.063 \\
\hline
\end{tabular}

(Al-OH) [15-19]. Above $600{ }^{\circ} \mathrm{C}$, no further loss of mass occurred in the clay yielding a total mass loss of $15.80 \%$. Likewise, CTKOH showed three events that were related to the mass loss of water from the clay [12-38]. The first event between 20 and $151{ }^{\circ} \mathrm{C}$ showed a loss of mass (PM1) of about $6.0 \%$ and was associated with the release of physically adsorbed water [12]. The second event occurred between 151 and $292{ }^{\circ} \mathrm{C}$ with a loss of mass (PM2) of $0.72 \%$. The third event with a less intense band than CNAT occurred in the range between 292 and 597 ${ }^{\circ} \mathrm{C}$ with loss of mass (PM3) of $2.03 \%$ and was related to water loss and loss of the hydroxyls of the silanol (Si-OH) and aluminol groups (Al-OH) [19-37]. Above $600{ }^{\circ} \mathrm{C}$, no further loss of mass occurred in the clay and therefore, a total mass loss of $9.08 \%$ was observed. The TG/DTG curves of $\mathrm{CTH}_{2} \mathrm{SO}_{4}$ revealed only two events. The first from 33 to $130{ }^{\circ} \mathrm{C}$ with loss of mass (PM1) of 7\%, and

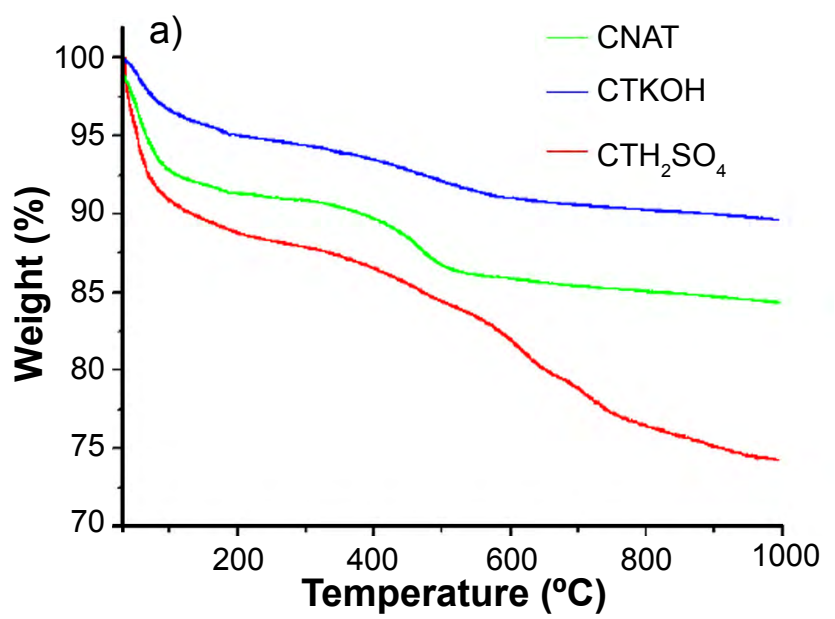

the second from 130 to $490{ }^{\circ} \mathrm{C}$ with a mass loss of $11 \%$, yielding a total mass loss of $18 \%$. The final temperatures of the two events were smaller in $\mathrm{CTH}_{2} \mathrm{SO}_{4}$ and the loss of total mass of clay was greater in $\mathrm{CTH}_{2} \mathrm{SO}_{4}$, which was likely due to the acid treatment which expedited the leaching of clay at lower temperatures [20-40]. It is worth remembering that the morphology is still preserved with acid treatment because the silica generated during the acid treatment could behave as a protective gel preserving the morphology of the clay minerals present $[19,20]$. The number of events and their respective mass loss found in thermal analysis of the samples CNAT, $\mathrm{CTH}_{2} \mathrm{SO}_{4}$, and CTPKOH are summarized in Table III.

Extraction and yield of the base oil: the yield of the pre-treated oil was calculated based on the ratio between the mass of recovered oil (free of alcohol) and water, and the mass of used oil [(MOrec/MOuse).100]. For the lubricating oil used for $15000 \mathrm{~km}$, the yield obtained by extraction with isoamyl alcohol was $78 \%$ by mass.

Physicochemical characterization of new lubricating oil (OLN), used lubricating oil (OLU), lubricating oil clarified with natural clay (OLCCNAT), lubricating oil clarified with clay treated with $\mathrm{KOH}$ (OLCCTKOH) and lubricant oil clarified with clay treated with $\mathrm{H}_{2} \mathrm{SO}_{4}\left(\mathrm{OLCCTH}_{2} \mathrm{SO}_{4}\right)$ : Table IV presents the results of physicochemical characterization of OLN, OLU, OLCCNAT, OLCCTKOH, and $\mathrm{OLCCTH}_{2} \mathrm{SO}_{4}$, compared to the limits of kinematic viscosity at 40 and $100^{\circ} \mathrm{C}$, ASTM color, acidity, and ash content established by the standards

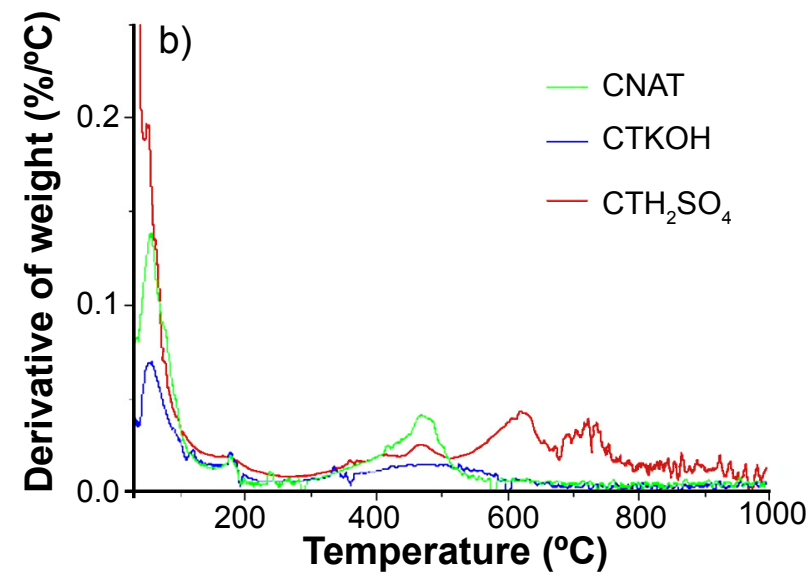

Figure 5: TG (a) and DTG (b), a derivative of TG, curves of the CNAT, CTKOH, and $\mathrm{CTH}_{2} \mathrm{SO}_{4}$ samples. $_{\text {sa }}$.

[Figura 5: Curvas TG (a) e DTG (b), derivada de TG, das amostras de CNAT, CTKOH e $\mathrm{CTH}_{2} \mathrm{SO}_{4}$.]

Table III - Results of thermal analysis of adsorbing materials.

[Tabela III - Resultados de análise térmica dos materiais adsorventes.]

\begin{tabular}{cccccccc}
\hline Sample & $\Delta \mathrm{T} 1\left({ }^{\circ} \mathrm{C}\right)$ & $\mathrm{PM} 1(\%)$ & $\Delta \mathrm{T} 2\left({ }^{\circ} \mathrm{C}\right)$ & $\mathrm{PM} 2(\%)$ & $\Delta \mathrm{T} 3\left({ }^{\circ} \mathrm{C}\right)$ & $\mathrm{PM} 3(\%)$ & PMT $(\%)$ \\
\hline CNAT & $20-126$ & 7.25 & $126-287$ & 1.50 & $287-600$ & 7.05 & 15.80 \\
$\mathrm{CTKOH}$ & $21-151$ & 6.33 & $151-292$ & 0.72 & $292-597$ & 2.03 & 9.08 \\
$\mathrm{CTH}_{2} \mathrm{SO}_{4}$ & $33-130$ & 7.00 & $130-490$ & 11.00 & - & - & 18.00 \\
\hline
\end{tabular}

UTi: temperature range of thermal event; PMi: loss of mass; PMT: total mass loss. 
Table IV - Results of physicochemical characterizations of OLN, OLU, OLCCNAT, OLCCTKOH, and OLCCTH $\mathrm{SO}_{4}$ compared with the limits from ASTM standards.

[Tabela IV - Resultados de caracterização físico química de OLN, OLU, OLCCNAT, OLCCTKOH e OLCCTH ${ }_{2} \mathrm{SO}_{4}$ comparados com limites de normas da ASTM.]

\begin{tabular}{cccccccc}
\hline Test & & OLN & OLU & OLCCNAT & OLCCTKOH & OLCCTH $_{2} \mathrm{SO}_{4}$ & Limit \\
\hline $\begin{array}{c}\text { Kinematic viscosity } \\
\left(\mathrm{mm}^{2} / \mathrm{s}\right)\end{array}$ & at $40^{\circ} \mathrm{C}$ & 100.2 & 114.0 & 34.5 & 30.6 & 27.5 & $26-32$ \\
ASTM color & at $100{ }^{\circ} \mathrm{C}$ & 16.8 & 18.7 & 14.0 & 9.5 & 7.4 & - \\
Acidity (mg KOH/g) & 1.0 & 8.0 & 6.5 & 6.0 & 5.0 & $\leq 3$ \\
Ash content (mass\%) & 2.09 & 5.97 & 0.048 & - & 0.045 & $\leq 0.05$ \\
\hline
\end{tabular}

OLN: new lubricating oil; OLU: used lubricating oil; OLCCNAT: lubricating oil clarified with natural clay; OLCCTKOH: lubricating oil clarified with clay treated with $\mathrm{KOH} ; \mathrm{OLCCTH}_{2} \mathrm{SO}_{4}$ : lubricant oil clarified with clay treated with $\mathrm{H}_{2} \mathrm{SO}_{4}$.

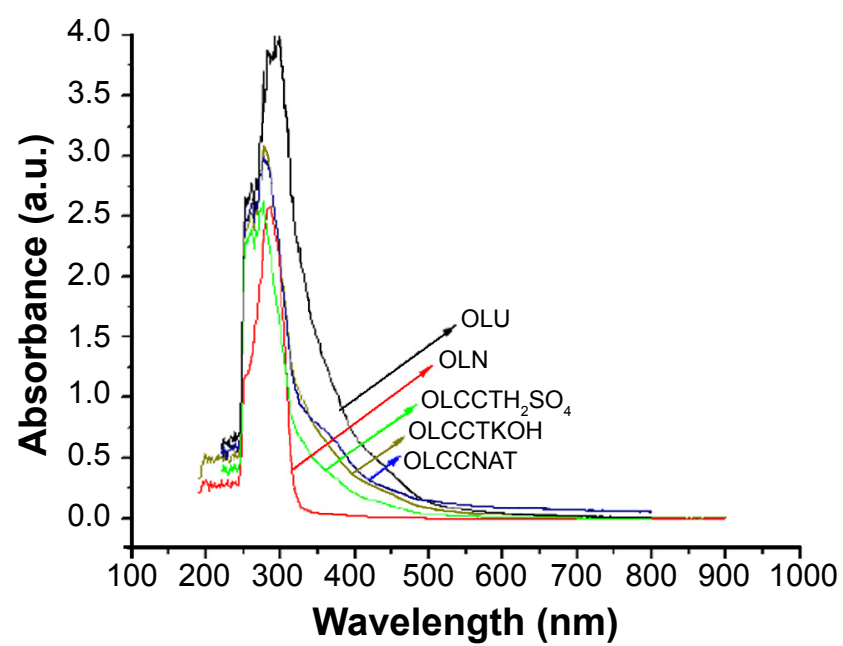

Figure 6: UV-vis absorption spectra of OLN, OLCCTKOH, OLCCNAT, OLCCTH $\mathrm{SO}_{4}$, and OLU.

[Figura 6: Espectros de absorção UV-vis de OLN, OLCCTKOH, OLCCNAT, $\mathrm{OLCCTH}_{2} \mathrm{SO}_{4}$ e OLU.]

ASTM D445-18, ASTM D1500-12, ASTM D974-04, and ASTM D482-13 that regulate the commercialization of recovered lubricating oils. After the recovery process of used lubricating oil (OLU) by extraction with isoamyl alcohol and adsorption with the clays, the results of the samples OLCCNAT, OLCCTKOH, and OLCCTH $\mathrm{SO}_{4}$ approached the limits established by ASTM [29-30]. $\mathrm{OLCCTH}_{2} \mathrm{SO}_{4}$ also presented the best whitening result of the used lubricating oil due to the creation of meso and microporous Bronsted-Lowry acidic sites, increasing the process of adsorption of metallic cations and dye. Moreover, the results found in this study were consistent with the results found in $[32,42]$. The absorbance spectrum in the wavelength range from 200 to $700 \mathrm{~nm}$ (Fig. 6) showed that the $\mathrm{OLCCTH}_{2} \mathrm{SO}_{4}$ clarified oil sample was the one that most closely approached the color of new lubricating oil (OLN), likely due to the adsorption of organic, inorganic, and metal contaminants on the adsorbent surface. This observation can be explained by hydrogen bonding capacity in Bronsted-Lowry sites that may form in clay enabled with sulfuric acid [43-46].

\section{CONCLUSIONS}

The use of natural and chemically modified clays is an environmentally friendly method of clarifying the used lubricating oil. The acid-treated sample was more efficient in dye adsorption, being responsible for the dark color of the used lubricating oil and, consequently, promoted effective oil clarification confirmed by the results obtained by the colorimeter and UV-vis analyses.

\section{REFERENCES}

[1] R.R. Mohammed, I.A.R. Ibrahim, A.H.T. McKay, Chem. Eng. J. 220 (2013) 343.

[2] T. Zaky, S.M. Tawfik, Fuel Process. Technol. 92 (2011) 447.

[3] J. Rincon, P. Canizares, M.T. García, Ind. Eng. Chem. Res. 44 (2005) 4373.

[4] E.A. Eman, A.M. Shoaib, Pet. Coal 55 (2013) 179.

[5] A.H. Durrani, I.M. Panhwar, A.R. Kazi, Mehran Univ. Res. J. Eng. Technol. 30 (2011) 237.

[6] M.A. Kamal, S.M.D. Naqvi, F. Khan, Sci. World J. 1 (2014) 1.

[7] O.C.J. Santos, G.M.I. Santos, G.A. Souza, V.E. Sobrinho, J.V. Fernandes, Fuel 83 (2004) 2393.

[8] A.M. Ghouti, L. Atoum, J. Environ. Manage. 90 (2009) 187.

[9] E. Arthur, M. Tuller, T. Norgaard, P. Moldrup, L.W. De Jonge, Geoderma 350 (2019) 40.

[10] S.L. Shiung, D.A. Russell, A.H. Chase, Energy 35 (2010) 2985.

[11] H. Wagner, R. Luther, T. Mang, Appl. Catal. A Gen. 221 (2001) 429.

[12] K.M.C. Xavier, M.S.F. Santos, J.A. Osajima, A.B. Luz, M.G. Fonseca, E.C. Silva Filho, Appl. Clay Sci. 119 (2016) 338.

[13] J.S. Patricio, D. Hotza, A. De Noni Júnior, Cerâmica 60, 354 (2014) 171.

[14] S.M.W. Ali, A. Ripin, A. Ahmad, J. Appl. Sci. 10 (2010) 2688.

[15] C. Duanmu, Y. Gu, Y. Qian, X. Gu, L. Feng, J. Jiang, Appl. Clay Sci. 55 (2012) 108. 
[16] P.S. Santos, Tecnologia de argilas 1, Edgard Blücher, S. Paulo (1975) 70.

[17] L. Boudrichea, R. Calvet, B. Hamdi, H. Balard, Colloid Surface A 392 (2011) 45.

[18] H. Chen, J. Zhao, A. Zhong, Y. Jin, Chem. Eng. J. 174 (2011) 143.

[19] E. Srasra, N. Frini-Srasra, Desalination 250 (2010) 26. [20] H.C. Starkey, D. Carrol, Clays Clay Miner. 19 (1971) 321.

[21] A. Kausar, M. Iqbal, A. Javed, K. Aftab, Zill-i-Huma, N.H.N. Bhatti, S. Nouren, J. Mol. Liq. 256 (2018) 395.

[22] Y. Jiang, A. Khan, H. Huang, Y. Tian, X. Yu, Q. Xu, L. Mou, J. Lv, P. Zhang, P. Liu, L. Deng, X. Li, Sci. Total Environ. 646 (2019) 606.

[23] A.I. Hafez, N.S. Gerges, H.N. Ibrahim, W.S.A. El Magd, A.I. Hashem, Egypt. J. Pet. 26 (2017) 533.

[24] S. Salem, A. Salem, A.A. Babaei, J. Ind. Eng. Chem. 23 (2015) 154.

[25] ASTM D1500-12, "Standard test method for ASTM color of petroleum products (ASTM color scale)", ASTM Int., West Conshohocken (2012).

[26] ASTM D445-18, "Standard test method for kinematic viscosity of transparent and opaque liquids (and calculation of dynamic viscosity)", ASTM Int., West Conshohocken (2018).

[27] ASTM D974-04, "Standard test method for acid and base number by color-indicator titration", ASTM Int., West Conshohocken (2004).

[28] ASTM D482-13, "Standard test method for ash from petroleum products", ASTM Int., West Conshohocken (2013).

[29] J.P. Neto, S.L.M. Almeida, R.M. Carvalho, in "Tecnologia mineral", 64, CETEM, Brazil (1993) 1.

[30] K.A. Sampaio, J. Vila-Ayala, S.M. Silva, R. Ceriane, R. Verhe, A.J.A.J. Meireles, J. Am. Oil Chem. Soc. 90 (2013) 191.

[31] T.E. Oladimeji, J.A. Sonibare, J.A. Omoleye, A.A.
Adegbola, H.I. Okagbuec, Data Brief 19 (2018) 2240.

[32] A.E.A. de Lima, H.B. Sales, L.C. de Lima, J.C.O.

Santos, I.M.G. dos Santos, A.G. de Souza, R. Rosenhain, Cerâmica 63, 368 (2017) 517.

[33] C. Stan, C, Andreescu, M. Toma, Procedia Manuf. 22 (2018) 709.

[34] D.I. Osman, S.K. Attia, R.A. Taman, Egypt. J. Pet. 27 (2018) 221.

[35] M.A. Morales-Carrera, C.D.F.A. Varajao, A.M. Goncalves, S.A. Stachissini, Quím. Nova 32 (2009) 2287.

[36] K.B. Amorim, R.S. Angélica, Cerâmica 57, 344 (2011) 483.

[37] W. Wang, G. Tian, Z. Zhang, A. Wang, Chem. Eng. J. 265 (2015) 228.

[38] A. Wang, W. Wang, Z. Zhang, Appl. Clay Sci. 107 (2015) 230.

[39] A. Wang, Y. Zhao, H. Chen, J. Hazard. Mater. 149 (2007) 346.

[40] R. Naidu, Y. Liu, J. Churchman, B. Biswas, B. Sarkar, R. Rusmin, Appl. Clay Sci. 134 (2016) 65.

[41] D. Papoulis, S. Komarneni, A. Nikolopoulou, P. TsolisKatagas, D. Panagiotaras, H.G. Kacandes, P. Zhange, S. Yin, T. Sato, H. Katsuki, Appl. Clay Sci. 50 (2010) 118.

[42] S.L.M. Melo, "Avaliação da qualidade dos óleos básicos rerrefinados brasileiros e a determinação de metais por espectrometria de fluorescência de raios X", Dr. Thesis, Un. Brasília (2015).

[43] I.M. Sato, J.O.W.V. Bustillos, C.L. Duarte, M.A. Scapin, Radiat. Phys. Chem. 78 (2009) 733.

[44] T. Chen, H. Liu, J. Li, D. Chen, D. Chang, D. Kong, R.L. Frost, Chem. Eng. J. 166 (2011) 1017.

[45] H. Chen, J. Zhao, A. Zhong, Y. Jin, Chem. Eng. J. 174 (2011) 143.

[46] E.L. Foletto, C. Volzone, A.F. Morgado, L.M. Porto, Cerâmica 47, 304 (2001) 208.

(Rec. 27/06/2019, Rev. 16/09/2019, 06/11/2019, 11/11/2019, Ac. 17/11/2019) 